\title{
PERSIAPAN TOTAL QUALITY MANAGEMENT (TQM)
}

\section{Fitriani $^{1}$}

\begin{abstract}
School is the main place in improving the quality and initial preparation to face the competition that exists today, namely by creating good and quality school management in accordance with the demands of TQM, because school management is a place to create quality and excellence. School management will be carried out if supported by human resources (HR) who have the ability, integration and high will. This is where the application of TQM that prioritizes quality reliability can be applied in the world of education to produce the best quality education in the school environment.
\end{abstract}

Keywords: Preparation Total Quality Management

\section{PENDAHULUAN}

Total Quality Management merupakan sistem manajemen yang mengangkat kualitas sebagai strategi usaha dan berorientasi pada kepuasan pelanggan dengan melibatkan seluruh anggota organisasi dan usaha yang mencoba untuk memaksimumkan daya saing organisasi melalui perbaikan terus menerus atas produk, jasa, manusia, prosesdan lingkungannya sehingga menghasilkan mutu yang tinggi. ${ }^{2}$

Gerakan TQM dimulai dibidang industri di Amerika Serikat antara pada tahun 1920 s/d 1940 dan di Jepang pada sekitar tahun 1950 tokohnya antara lain Deming, Sheward, dan Juran yang menyatakan bahwa mulailah dengan apa yang diinginkan pelanggan, selain organisasi juga memiliki standar yang tinggi. Berdasarkan ide tersebut, Jepang mengembangkannya dan ternyata berhasil. Keberhasilan ini dianggap suatu revolusi dalam bidang manajemen dari uraian di atas sebenarnya menunjuk pada organisasi yang unggul/bermutu adalah: organisasi yang harus dekat dengan pelanggan, memiliki obsesi mutu, memiliki birokrasi berdasarkan aktivitas dan antusias anggota. ${ }^{3}$

Berbagai upaya untuk meningkatkan mutu pendidikan kini sebenarnya telah, sedang, dan akan terus dilaksanakan secara bertahap dan berkelanjutan. Mulai dari

\footnotetext{
${ }^{1}$ Dosen Program Studi Manajemen Pendidikan Islam Institut Agama Islam Negeri (IAIN) Bone.

${ }^{2}$ Edward Sallis, Total Quality Management in Education(Jogjakarta, Ircisod, 2010), h. 49-53.

${ }^{3}$ http://www.scribd.com/doc/65158465/1/Sejarah-Perkembangan-Total-Quality-Management (diakses tanggal 06 oktober 2013).
} 
peningkatan kualitas pendidikan pra sekolah, dasar, menengah, sampai dengan perguruan tinggi. Salah satu upaya yang kini sedang disosialisasikan dan dianggap tepat adalah melalui Total Quality Manajement (TQM) atau manajemen mutu terpadu. Esensi dari TQM adalah suatu filosofi dan menunjuk pada perubahan budaya dalam suatu organisasi (pendidikan), serta dapat menyentuh hati dan pikiran orang menuju mutu yang diidamkan.

TQM masuk dalam bidang pendidikan pada sekitar tahun 1980 utamanya dilaksanakan di perguruan tinggi hingga Pendidikan dasar. Upaya itu terus menerus meningkat di Inggris dan Amerika pada tahun 1990. Fokus utamanya pada peningkatan kualitas pendidikan melalui reorganisasi praktek pendidikan. Keberhasilan TQM ini dapat dilihat dari pernyataan bahwa jaminan kualitas pendidikan sangat diperlukan dan agar setiap lembaga pendidikan menetapkan sistem TQM-nya.

Tujuan utama TQM dalam bidang pendidikan adalah meningkatkan mutu pendidikan secara berkelanjutan, terus menerus, dan terpadu. Upaya peningkatan mutu pendidikan yang dimaksudkan tidak sekaligus, melainkan dituju berdasarkan peningkatan mutu pada setiap komponen pendidikan. ${ }^{4}$

Pencapaian tujuan di atas dapat dicapai jika menggunakan prinsip-prinsip sebagai berikut pemfokusan pada pelanggan atau peserta didik, peningkatan kualitas pada proses, dan melibatkan semua komponen pendidikan pemfokusan pada pengguna menunjuk pada setiap peningkatan kualitas pendidikan haruslah didasarkan pada keinginan, kebutuhan, dan harapan pengguna pendidikan internal dan eksternal. Konsep ini memerlukan plan, do, check, action pengumpulan dan penganalisaan data lapangan secara tepat sehingga perlu mempertemukan kedua belah pihak. ${ }^{5}$

Oleh karena itu, sekolah merupakan tempat utama dalam memperbaiki kualitas dan persiapan awal untuk menghadapi kompetisi yang ada pada zaman sekarang ini.

\footnotetext{
${ }^{4}$ Hasil kesimpulan dari perkuliahan dengan Mardiyah pada tanggal 2 Oktober 2013.

${ }^{5}$ Fandy Tjiptono dan Anastasia Diana, Total Quality Management Edisi Revisi (Yogyakarta: Andi, 2003), h. 331-335.
} 
Yaitu dengan cara menciptakan manajemen sekolah yang baik dan berkwalitas sesuai dengan tuntutan TQM, karena manajemen sekolah adalah tempat untuk menciptakan kualitas dan keunggulan tersebut. Manajemen sekolah akan terlaksana jika didukung dengan sumber daya manusia (SDM) yang memiliki kemampuan, integrasi dan kemauan yang tinggi. Dari sinilah penerapan TQM yang memprioritaskan kehandalan mutu dapat diterapkan dalam dunia pendidikan guna menghasilkan kualitas pendidikan terbaik di lingkungan sekolah.

\section{PEMBAHASAN}

Implementasi TQM bukanlah suatu pendekatan yang sifatnya langsung jadi atau hasilnya diperoleh dalam waktu sekejap, tetapi membutuhkan suatu proses yang sistematis, adapun tahapan-tahapan implementasi TQM menurut Goetsch dan Davis yang dikutip oleh Fandy dalam bukunya Total Quality Management memberikan klasifikasi fase implementasi TQM dikelompokkan menjadi tiga fase yaitu fase persiapan, fase perencanaan, dan fase pelaksanaan, masing-masing fase terdiri dari atas beberapa langkah di mana waktu yang dibutuhkan untuk setiap langkah tergantung pada organisasi yang menerapkanya. ${ }^{6}$ Adapun yang akan dibahas oleh penulis adalah fase persiapan.

\section{Fase Persiapan}

1. Membentuk Total Quality Steering Committee

An advisory committee usually made up of high level stakeholders or experts who provide guidance on key issues such as company policy and objectives, budgetary control, marketing strategy, resource allocation, and decisions involving large expenditures. ${ }^{7}$ (Sebuah komite penasehat biasanya terdiri dari pemangku kepentingan tingkat tinggi atau ahli yang memberikan panduan tentang isu-isu kunci

\footnotetext{
${ }^{6}$ Fandy Tjiptono dan Anastasia Diana, Total Quality Management h. 343.

${ }^{7}$ http://www.businessdictionary.com/definition/steering-committee.html(diakses tanggal 06 oktober 2013).
} 
seperti kebijakan perusahaan dan tujuan, kontrol anggaran, strategi pemasaran, alokasi sumber daya, dan keputusan yang melibatkan pengeluaran besar).

a. Membentuk Tim

Tim TQM dua orang atau lebih yang secara sukarela bekerjasama untuk mencapai hasil hasil yang bermutu, aktivitas tim banyak mengangkat nilai-nilai organisasi, dan tim mengarahkan perhatian permasalahan-permasalahan yang berhubungan dengan kepelangganan internal atau ekternal, keberadaan tim memberi otoritas untuk mengerjakan hal-hal yang berkaitan dengan mutu dan mekanisme untuk mengendalikan dan memantau proses kebijakan dan prosedur. ${ }^{8}$

Dalam organisasi yang menerapkan TQM, kerja sama tim, kemitraan dan hubungan dijalin dan dibina baik antar karyawan perusahaan maupun dengan pemasok lembaga-lembaga pemerintah, dan masyarakat sekitarnya.

\section{b. Pelatihan TQM}

Mutu didasarkan pada ketrampilan setiap karyawan yang pengertiannya tentang apa yang dibutuhkan oleh pelanggan ini mencakup mendidik dan melatih semua karyawan, memberikan baik informasi yang mereka butuhkan untuk menjamin perbaikan mutu dan memecahkan persoalan. Pelatihan inti ini memastikan bahwa suatu bahasa dan suatu set alat yang sama akan diperbaiki di seluruh perusahaan. Pelatihan tambahan pada bench marking, statistik dan teknik lainnya juga dipergunakan dalam rangka mencapai kepuasan pelanggan yang paripurna. $^{9}$

c. Menyusun Pernyataan Visi dan Prinsip sebagai Pedoman

Visi merupakan gambaran tentang masa depan future yang realistik dan ingin diwujudkan dalam kurun waktu tertentu. Visi adalah pernyataan yang 2009), h. 541.

${ }^{8}$ Veithzal Rivai, M.B.A. Education Management Analisis Teori dan Praktik (Jakarta: Rajawali Pers,

${ }^{9}$ http://bagoezw.wordpress.com/2008/04/19/penerapan-tqm-total-quality-managementdalam/(diakses tanggal 06 oktober 2013). 
diucapkan atau ditulis hari ini, yang merupakan proses manajemen saat ini yang menjangkau masa yang akan datang. ${ }^{10}$

Bagi suatu organisasi visi memiliki peranan yang penting dalam menentukan arah kebijakan dan karakteristik organisasi tersebut. Ada beberapa hal yang harus diperhatikan dalam merumuskan sebuah visi menurut Bryson antara lain:

1) Visi harus dapat memberikan panduan/arahan dan motivasi.

2) Visi harus desebarkan di kalangan anggota organisasi (stakeholder).

3) Visi harus digunakan untuk menyebarluaskan keputusan dan tindakan organisasi yang penting. ${ }^{11}$

Misi merupakan tindakan atau upaya untuk mewujudkan visi. Jadi misi merupakan penjabaran visi dalam bentuk rumusan tugas, kewajiban, dan rancangan tindakan yang dijadikan arahan untuk mewujudkan visi. Dengan kata lain, misi adalah bentuk layanan untuk memenuhi tuntutan yang dituangkan dalam visi dengan berbagai indikatornya.

Ada beberapa kriteria dalam pembuatan misi, antara lain:

1) Penjelasan tentang produk atau pelayanan yang ditawarkan yang sangat diperlukan oleh masyarakat.

2) Harus jelas memiliki sasaran publik yang akan dilayani.

3) Kualitas produk dan pelayanan yang ditawarkan memiliki daya saing yang meyakinkan masyarakat.

4) Penjelasan aspirasi bisinis yang diinginkan pada masa mendatang juga bermanfaat dan keuntungannya bagi masyarakat dengan produk dan pelayanan yang tersedia ${ }^{12}$.

${ }^{10}$ Akdon, Strategic Managemen for Educational Management (Bandung: Alfabeta, 2006), h. 94. 2001), h. 2013

${ }^{11}$ M. John Bryson, Perencanaan Strategis bagi Organisasi Sosial (Yogyakarta: Pustaka Pelajar,

${ }^{12}$ Akdon, Strategic Managemen for Educational Management h. 98-99. 
d. Menyusun Tujuan Umum

Setelah visi misi dan nilai-nilai telah ditetapkan, ketiganya harus diterjemahkan kedalam tujuan-tujuan yang dapat dicapai. Tujuan sering diekspresikan sebagai sasaran dan cita-cita dan sebuah metode yang dapat diukur sehingga hasil akhirnya dapat dievaluasi dengan menggunakan metode tersebut tujuan harus realistis dan dapat dicapai. ${ }^{13}$

Dengan adanya tujuan yang jelas maka suatu pekerjaan akan jelas pula arahnya, lebih-lebih pekerjaan mendidik yang bersasaran psikologi manusia didik yang masih berada pada taraf perkembangan, maka tujuan merupakan faktor yang paling penting dalam proses pendidikan, oleh karena dengan adanya tujuan yang jelas materi pelajaran dan metode-metode yang digunakan mendapat corak dan isi serta potensialitas yang sejalan dengan cita-cita yang terkandung dalam visi misi. ${ }^{14}$

e. Komunikasi dan Publikasi

Sebuah institusi harus memberikan informasi yang jelas tentang apa yang ditawarkan dalam program pembelajarannya kepada para calon dan pelanggannya, informasi ini secara jelas harus didokumentasikan dan dipersiapkan, misalnya materi-materi, iklan brosur dan lain-lain harus jelas dan akurat dan diperbaharui secara teratur. ${ }^{15}$

Komunikasi dalam suatu lingkungan mutu perlu ditempuh dengan cara berbeda-beda agar dapat berkomunimasi kepada seluruh karyawan mengenai suatu komitmen yang sungguh-sungguh untuk melakukan perubahan dalam usaha peningkatan mutu. Secara ideal manajer harus bertemu pribadi dengan para karyawan untuk menyampaikan informasi, memberikan pengarahan, dan menjawab pertanyaan dari setiap karyawan.

\footnotetext{
${ }^{13}$ Fandy Tjiptono dan Anastasia Diana, Total Quality Management h. 219.

${ }^{14}$ Ramayulis, Ilmu Pendidikan Islam (Jakarta: Kalam Mulia, 2002), h. 148.

${ }^{15}$ Edward Sallis, Total Quality h. 256.
} 
f. Identifikasi Kekuatan dan Kelemahan

Dalam dunia pendidikan analisis ini digunakan untuk mengevaluasi fungsi pengembangan kurikulum, fungsi perencanaan dan evaluasi, fungsi ketenagaan, fungsi keuangan, fungsi proses belajar mengajar, fungsi pelayanan kesiswaan, fungsi pengembangan iklim akademik, fungsi hubungan sekolah dengan masyarakat dan sebagainya dilibatkan.

Identifikasi kekuatan dan kelemahan bisa menggunakan analisa SWOT yaitu singkatan dari Strengths, Weaknesses, Opportunities, and Threats, yaitu (kekuatan, kelemahan, peluang, dan ancaman) analisis SWOT dapat dibagi kedalam dua elemen yaitu analisa internal yang berkonsentrasi pada prestasi institusi itu sendiri dan analisis pada lingkungan ${ }^{16}$

$S=$ Strength adalah situasi atau kondisi yang merupakan kekuatan dari organisasi atau program pada saat ini. $W=$ Weakness adalah situasi atau kondisi yang merupakan kelemahan dari organisasi atau program pada saat ini. $O=$ Opportunity adalah situasi atau kondisi yang merupakan peluang di luar organisasi dan memberikan peluang berkembang bagi organisasi di masa depan. $T=$ Threat adalah situasi yang merupakan ancaman bagi organisasi yang datang dari luar organisasi dan dapat mengancam eksistensi organisasi di masa depan.

Analisis SWOT dilakukan dengan maksud untuk mengenali tingkat kesiapan setiap fungsi dari keseluruhan fungsi sekolah yang diperlukan untuk mencapai sasaran yang telah ditetapkan. Berhubung tingkat kesiapan fungsi ditentukan oleh tingkat kesiapan masing-masing faktor yang terlibat pada setiap fungsi, maka analisis SWOT dilakukan terhadap keseluruhan faktor dalam setiap fungsi, baik faktor internal maupun eksternal.

\footnotetext{
${ }^{16}$ Edward Sallis, Total Quality h.221.
} 


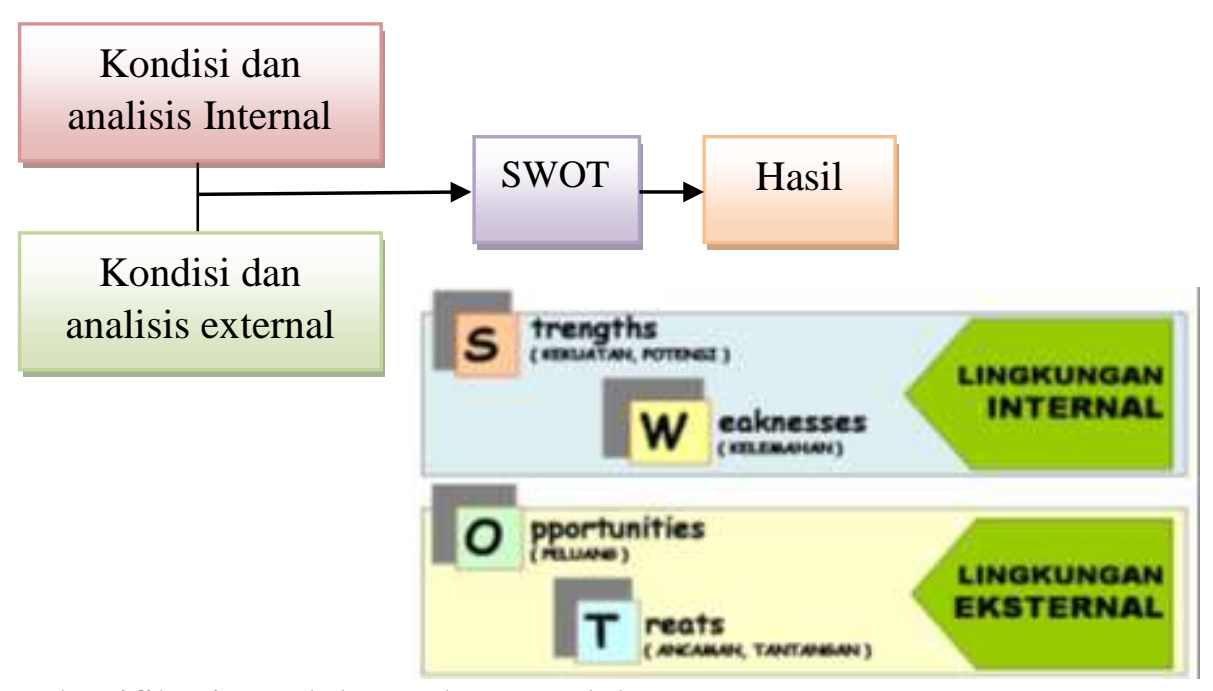

g. Identifikasi Pendukung dan Penolak

Analisis kekuatan lapangan adalah alat yang berguna untuk mempelajari sesuatu yang memerlukan perubahan, ini didasarkan pada dua ide bahwa ada dua kekuatan yang saling berhadapan dalam sebuah usaha perubahan. Kekuatan pertama mendukung pada perubahan, sedangkan yang lain menolak yang lain, analisis tersebut memberikan sebuah tawaran yang bias dilakukan yaitu memperkuat kekuatan pendukung dan menetralkan kekuatan yang menolak. ${ }^{17}$

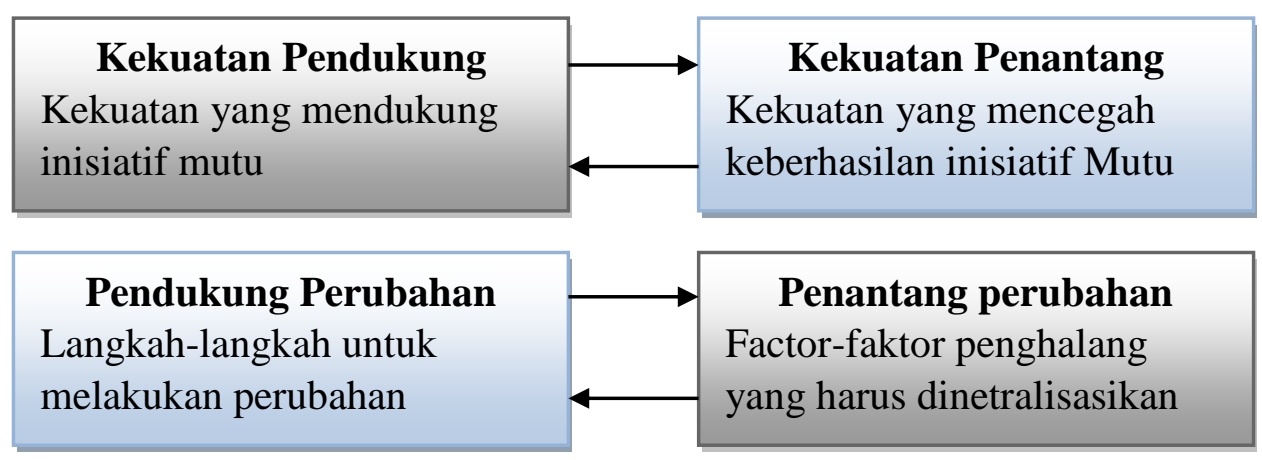

Identifikasi Pendukung dan Penolak bisa dilakukan dengan siklus PDSA yaitu Plan, Do, Study Check, Action, siklus PDSA adalah temuan Shewhart yang juga digunakan oleh Deming yang telah dimodifikasi oleh Deming menjadi PDCA Plan, Do, Check, Action. ${ }^{18}$

\footnotetext{
${ }^{17}$ Edward Sallis, Total Quality h. 203.

${ }^{18}$ Veithzal Rivai, M.B.A. Education Management h. 553.
} 


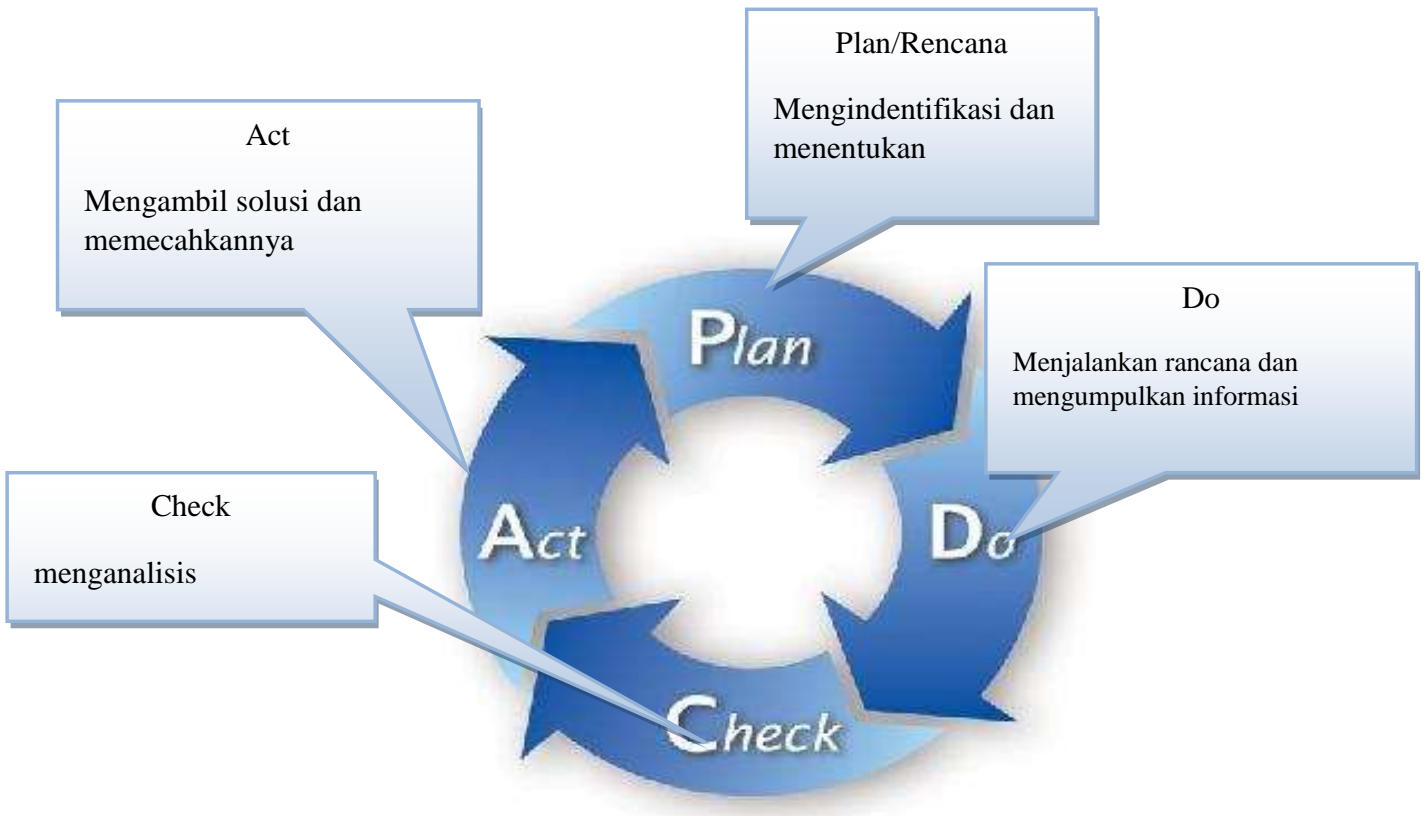

h. Memperkirakan Sikap Karyawan

Sikap merupakan kecenderungan individu untuk merespon dengan cara yang khusus terhadap stimulus yang ada dalam lingkungan sosial. Sikap merupakan suatu kecenderungan untuk mendekat atau menghindar, posotitif atau negative terhadap berbagai keadaan sosial, apakah itu institusi, pribadi, situasi, ide.

i. Mengukur Kepuasan Pelanggan

Kepuasan pelanggan adalah suatu keadaan menyangkut keinginan, harapan dan kebutuhan pelanggan dipenuhi. Suatu pelayanan dinilai memuaskan bila pelayanan tersebut dapat memenuhi kebutuhan dan harapan pelanggan. Pengukuran kepuasan pelanggan merupakan elemen penting dalam menyediakan pelayanan yang lebih baik, lebih efisien dan lebih efektif. Apabila pelanggan merasa tidak puas terhadap suatu pelayanan yang disediakan, maka pelayanan tersebut dapat dipastikan tidak efektif dan tidak efisien. Hal ini terutama sangat penting bagi instansi pelayanan publik.

Tingkat kepuasan pelanggan terhadap pelayanan merupakan faktor yang penting dalam mengembangkan suatu sistim penyediaan pelayanan yang tanggap 
terhadap kebutuhan pelanggan, meminimalkan biaya dan waktu serta memaksimalkan dampak pelayanan terhadap populasi sasaran. ${ }^{19}$

Ada empat metode yang dapat digunakan setiap perusahaan untuk mengukur dan memantau kepuasan pelanggan (juga pelanggan perusahaan pesaing). Empat teknik untuk mengukur kepuasan pelanggan yaitu:

1) Sistem keluhan dan saran

Setiap perusahaan yang berorientasi pada pelanggan (customer oriented) perlu memberikan kesempatan seluas-luasnya bagi para pelanggannya untuk menyampaikan saran, pendapat, dan keluhan mereka. Media yang dapat digunakan meliputi kotak saran yang diletakkan ditempat strategis, menyediakan kartu komentar (guest comment), menyediakan saluran telephone khusus dan lain-lain. Informasi yang diperoleh melalui ini dapat memberikan ide-ide baru dan masukan yang berharga kepada perusahaan. Sehingga memungkinkan untuk memberikan respon secara tepat dan yang tanggap setiap masalah yang timbul.

2) Survei kepuasan pelanggan

Umumnya banyak penelitian mengenai kepuasan konsumen dilakukan dengan menggunakan metode survei, baik melalui pos, telephone maupun wawancara balik secara langsung dari konsumen. Pengukuran kepuasan pelanggan melalui metode ini dapat dilakukan berbagai cara diantaranya:

a) Directly Reported Satisfaction

Pengukuran dilakukan secara langsung melalui pertanyaan seperti ungkapan “seberapa puas saudara terhadap pelayanan perusahaan A pada skala berikut: sangat tidak puas, netral, puas, sangat puas.

${ }^{19} \mathrm{http}$ ///isodinkeskebumen.blogspot.com/2012/02/pengukuran-kepuasan-pelanggan-sesuai.html di akses tanggal 11 Oktober 2013. 


\section{b) Derived Dissatisfaction}

Pertanyaan yang diajukan yakni besarnya harapan pelanggan terhadap atribut tertentu dan besarnya kinerja yang mereka rasakan.

c) Problem Analysis

Konsumen yang dijadikan responden diminta untuk mengungkapkan dua hal pokok, pertama, masalah yang mereka hadapi berkaitan dengan penawaran dari perusahaan, kedua, saran-saran untuk melakukan analisis.

d) Importance-performance analysis

Dalam teknik ini responden diminta untuk merangking berbagai elemen (atributo) dari penawaran berdasarkan derajat pentingnya setiap elemen. Selain itu responden yang diminta untuk merangking seberapa baik kinerja perusahaan dalam masing-masing elemen tersebut.

\section{3) Ghost shopping}

Metode ini dilaksanakan dengan mempekerjakan beberapa orang ghost shopper untuk berperan dan bersikap seperti pelanggan atau pembeli yang potensial dari produk perusahaan dan pesaing. Lalu mereka menyampaikan temuantemuannya mengenai kekuatan dan kelemahan produk perusahaan dan perusahaan pesaing, berdasarkan pengalaman mereka juga mengamati dan menilai cara perusahaan pesaingnya menjawab pertanyaan pelanggan dan menangani setiap keluhan.

\section{4) Lost customer analysis}

Metode ini cukup unik. Perusahaan berusaha menghubungi para pelanggannya yang telah berhenti membeli atau beralih pemasok. Yang diharapkan adalah akan diperolehnya informasi penyebab terjadinya hal tersebut. Informasi ini sangat bermanfaat bagi perusahaan untuk mengambil kebijakan selanjutnya dalam rangka meningkatkan kepuasan dan loyalitas pelanggan. ${ }^{20}$ 


\section{PENUTUP}

Total Quality Management memberikan klasifikasi fase implementasi TQM dikelompokkan menjadi tiga fase yaitu fase persiapan, fase perencanaan, dan fase pelaksanaan, masing-masing fase terdiri dari atas beberapa langkah di mana waktu yang dibutuhkan untuk setiap langkah tergantung pada organisasi yang menerapkanya.

\section{Fase Persiapan}
a. Membentuk Total Quality Steering Committee
b. Membentuk Tim
c. Pelatihan TQM
d. Menyusun Pernyataan Visi dan Prinsip sebagai Pedoman
e. Menyusun tujuan umum
f. Komunikasi dan Publikasi
g. Identifikasi Kekuatan dan Kelemahan
h. Identifikasi Pendukung dan Penolak
i. Memperkirakan Sikap Karyawan
j. Mengukur Kepuasan Pelanggan

\section{DAFTAR RUJUKAN}

Akdon, Strategic Managemen for Educational Management. Bandung: Alfabeta, 2006.

Bryson, M. John. Perencanaan Strategis Bagi Organisasi Sosial. Yogyakarta: Pustaka Pelajar. 2001.

Edward Sallis, Total Quality Management in Education. Jogjakarta, Ircisod, 2010.

http://bagoezw.wordpress.com/2008/04/19/penerapan-tqm-total-quality-managementdalam/

http://isodinkeskebumen.blogspot.com/2012/02/pengukuran-kepuasan-pelanggansesuai.html di akses tanggal 11 Oktober 2013.

http://sharingbahankuliah.blogspot.com/2009/11/alat-mengukur-kepuasan-pelanggan.html 11 oktober 2013.

http://www.businessdictionary.com/definition/steering-committee.html

Rivai, Veithzal M.B.A. Education Management Analisis Teori dan Praktik. Jakarta: Rajawali Pers, 2009.

Tjiptono, Fandy dan Anastasia Diana. Total Quality Management. Edisi Revisi. Yogyakarta: Andi, 2003. 